\title{
ANALISIS PENERAPAN PSAK NO. 23 TENTANG PENDAPATAN PADA PT. PEGADAIAN CABANG MEGAMAS MANADO
}

\author{
Claudia Relia Musadi ${ }^{1}$, Herman Karamoy $^{2}$, Hendrik Gamaliel ${ }^{3}$ \\ ${ }^{1,2,3}$ Jurusan Akuntansi, Fakultas Ekonomi dan Bisnis, Universitas Sam Ratulangi, Jl. Kampus Bahu, Manado, \\ 95115, Indonesia
}

E-mail : cmusadi@yahoo.com

\begin{abstract}
Revenue is one of the most important elements of the formation of income statement within a company. Revenue is due to the company's activities in utilizing production factors for self-sustaining and growth. This research was conducted at PT. Pegadaian Cabang Megamas Manado, a company engaged in financial services whose main activity is to disburse loan money on the basis of legal lien. The purpose of this study is to analyze the process of recognition, pemgukuran, and disclosure of income from PT. Pegadaian Cabang Megamas Manado by using PSAK No. 23 on Revenue as a comparison. The method used is qualitative research method, that is descriptive analysis. The results showed, the recognition of income at PT. Pegadaian Cabang Megamas Manado is recognized based on accrual basis in which income is recognized upon acquisition of goods or services. The measurement of income is recorded at the amount of cash received or at fair value provided for the income. Revenue disclosures are made on the basis of each income post. Recognition, measurement, and disclosure of income at PT. Pegadaian Cabang Megamas Manado is in accordance with PSAK No. 23.
\end{abstract}

Keywords: Revenue, Recognition, Measurement, Disclosure

\section{PENDAHULUAN}

Setiap perusahaan yang didirikan memiliki tujuan agar dapat memperoleh laba semaksimal mungkin untuk keberlangsungan hidup perusahaan. Agar tujuan tersebut dapat tercapai, sangat dibutuhkan kecermatan, ketelitian, dan keakurasian pelaksanaan atau pengelolaan perusahaan dalam melakukan sinergitas antara masing-masing bagian dalam organisasi perusahaan untuk bisa lebih kuat. Pada gilirannya dapat tercapai kebijakankebijakan yang sinergi dan terintegral secara utuh dari setiap bagian-bagian pada perusahaan sehingga keberhasilan dari tujuan dapat terealisasi.

Apabila suatu pendapatan diakui tidak sama dengan yang seharusnya, maka ini berarti pendapatan bisa salah (terlalu besar atau terlalu kecil). Hal ini dapat mengakibatkan informasi yang disajikan dalam laporan laba rugi tidak tepat dan dapat mengakibatkan kesalahan dalam pengambilan keputusan oleh pihak manajemen perusahaan. Sehingga penting sekali dalam pengakuan dan pengukuran pendapatan, perusahaan menggunakan suatu standar sebagai acuan, yaitu Standar Akuntansi Keuangan (SAK), khususnya PSAK No. 23.

PT. Pegadaian merupakan salah satu BUMN yang memberikan pelayanan kepada masyarakat dalam bentuk pemberian kredit berdasarkan hukum gadai yang berlaku untuk siapa saja dengan barang jaminan berupa benda-benda bergerak. Pegadaian di Indonesia pertama kali didirikan pada tahun 1901, dan pada tahun 1990 pegadaian berubah status badan hukumnya menjadi perusahaan perseroan. Sejak didirikan hingga saat ini PT. Pegadaian memiliki lebih dari 4.000 cabang yang tersebar di seluruh Indonesia, salah satunya adalah PT. Pegadaian Cabang Mega Mas. Berdasarkan latar belakang maka rumusan masalah dalam penelitian ini adalah :

1. Bagaimana proses pengakuan pendapatan pada PT. Pegadaian (PERSERO) Cabang Megamas Manado? 
2. Bagaimana proses pengukuran pendapatan pada PT. Pegadaian (PERSERO) Cabang Megamas Manado?

3. Bagaimana proses pengungkapan pendapatan pada PT. Pegadaian (PERSERO) Cabang Megamas Manado?

4. Apakah proses pengakuan, pengukuran, dan pengungkapan pendapatan pada PT. Pegadaian (PERSERO) Cabang Megamas Manado telah diterapkan sesuai dengan PSAK No. 23 ?

Tujuan penelitian ini adalah untuk menganalisis proses pengakuan, pengukuran, dan pengungkapan dari PT. Pegadaian (PERSERO) Cabang Megamas Manado dengan menggunakan PSAK No. 23 tentang Pendapatan sebagai pembanding. Manfaat yang diharapkan dari penelitian ini adalah sebagai berikut:

1. Penelitian ini merupakan suatu media untuk menerapkan pengetahuan yang telah diperoleh peneliti selama ini, khususnya penerapan PSAK pada perusahaan.

2. Menjadi bahan masukan dan pertimbangan bagi PT. Pegadaian Cabang Megamas Manado tentang pengakuan, pengukuran, dan pengungkapan pendapatan sesuai PSAK No. 23.

3. Menjadi bahan refrensi dan pertimbangan bagi para peneliti yang berminat dalam penelitian yang berhubungan dengan pengakuan, pengukuran, dan pengungkapan pendapatan sesuai PSAK No. 23.

\section{TINJAUAN PUSTAKA}

\subsection{Konsep Akuntansi}

Akuntansi merupakan bahasa bisnis yang dapat memberikan informasi tentang kondisi bisnis dan hasil usahanya pada suatu waktu atau periode tertentu (Harahap, 2013:2). Selain itu, akuntansi adalah system informasi dan pengukuran yang relevan, dapat diandalkan, dan dapat dibandingkan tentang kegiatan bisnis organisasi (Wild, Shaw dan Chiappette, 2014:3

\subsection{Konsep Akuntansi Keuangan}

Akuntansi keuangan berhubungan dengan masalah pencatatan transaksi untuk suatu perusahaan atau organisasi dan penyusunan berbagai laporan berkala dari hasil pencatatan (Pontoh, 2013:2).

\subsection{Pendapatan}

\subsubsection{Pengertian Pendapatan}

Pendapatan adalah "arus masuk atau peningkatan lainnya atas aktiva sebuah entitas atau penyelesaian kewajiban (atau kombinasi dari keduanya) selama satu periode dari pengiriman atau produksi barang, penyediaan jasa, atau aktivitas lain yang merupakan operasi utama atau sentral entitas yang sedang berlangsung." (Dyckman, 2012:82). Pendapatan merupakan hasil imbalan terhadap adanya penyerahan barang atau jasa yang telah diproduksi dalam operasi perusahaan. Pendapatan merupakan unsur yang paling utama dalam menentukan tingkat laba yang dapat dilihat sebagai prestasi perusahaan dalam mengoperasikan perusahaannya dalam suatu periode tertentu.

Menurut Rudianto (2013:56) secara garis besar pengertian pendapatan dapat ditinjau dari dua sisi, yaitu sebagai berikut:

1. Menurut Ilmu Ekonomi

2. Menurut Ilmu Akuntansi

\subsubsection{Karakteristik Pendapatan}

Pendapatan diakibatkan oleh kegiatan-kegiatan perusahaan dalam memanfaatkan faktor-faktor produksi untuk mempertahankan diri dan pertumbuhan. Seluruh kegiatan perusahaan yang menimbulkan pendapatan secara keseluruhan disebut earning process. Secara garis besar earning process menimbulkan dua akibat yaitu pengaruh postif atau 
pendapatan dan keuntungan juga pengaruh negatif atau beban dan kerugian. Selisih dari keduanya nantinya menjadi laba dan rugi.

IAI melalui PSAK No.23 mengungkapkan sumber pendapatan adalah sebagai berikut:

1) Penjualan Barang

2) Penjualan Jasa

3) Bunga, Royalti, dan Dividen

4) Pertukaran Barang atau Jasa

2.3.3 Klasifikasi Pendapatan

Pendapatan diklasifikasikan sebagai berikut:

1. Pendapatan usaha (operasional)

2. Pendapatan non-usaha (Non Operasional)

2.4 Pengakuan Pendapatan

\subsubsection{Pengertian Pengakuan Pendapatan}

Pengakuan sebagai pencatatan suatu item dalam akuntansi dan laporan keuangan seperti aktiva, kewajiban, pendapatan, beban, keuntungan, atau kerugian. Pengakuan termasuk penggambaran suatu item baik dalam kata maupun dalam jumlah, dimana jumlah mencakup angka-angka ringkas yang dilaporkan dalam laporan keuangan. Pengakuan adalah "recognition is the process of formally recording or incorporating an item in the acoounts and financial statements of an entity". Pengakuan adalah proses untuk mencatat atau memasukkan secara formal suatu pos dalam akun dan laporan keuangan entitas (Kieso, 2012:110).

\subsubsection{Kriteria Pengakuan Pendapatan}

Pengakuan sebagai pencatatan suatu item dalam perkiraan-perkiraan dan laporan keuangan seperti aktiva, kewajiban, pendapatan, beban, keuntungan, kerugian. Pengakuan itu termasuk penggambaran suatu item baik dalam kata-kata maupun dalam jumlahnya, dimana jumlah mencakup angka-angka ringkas yang dilaporkan dalam laporan keuangan.

Empat kriteria mendasar yang harus dipenuhi sebelum suatu item diakui, yaitu sebagai berikut:

1. Definisi (Definition)

2. Dapat diukur (Measurability)

3. Relevan (Relevance)

4. Reliabilitas (Realibility)

\subsubsection{Prinsip Pengakuan Pendapatan}

Suhayati (2009:45) pada umumnya, pendapatan diakui pada saat berikut ini:

1. Menerima uang (cash basic)

2. Terjadinya transaksi/tidak secara tunai (accrual basis)

3. Terjadinya penjualan (sales basis)

\subsubsection{Metode Pengakuan Pendapatan}

Ada dua metode yang dipergunakan dalam pengakuan pendapatan (Kieso, 2012:125), yaitu sebagai berikut:

1. Accrual Basis (Dasar Akrual)

2. Cash Basis (Dasar Kas)

\subsection{Pengukuran Pendapatan}

\subsubsection{Pengertian Pengukuran Pendapatan}

Apabila suatu pedapatan telah diakui sebagai pendapatan, maka kemudian masalah yang harus dijawab adalah masalah mengenai pengukuran pendapatan yang telah diakui tersebut. Pengukuran ialah pemberian nilai dan atribut-atribut pengukuran akuntansi pada item tertentu dari suatu transaksi berdasarkan satuan ukur uang. Jadi antara pengakuan dan pengukuran suatu item terlebih dahulu ditetapkan pengakuannya, kemudian ditentukan nilainya. 
Pengukuran pendapatan sangat penting untuk setiap transaksi yang menimbulkan pendapatan agar dapat menghasilkan informasi yang akurat untuk pengambilan keputusan oleh manajemen. Pengukuran pendapatan juga dapat dinyatakan dalam perolehan kas atau setara kas. Tanpa pengukuran yang tepat kinerja perusahaan akan sulit diketahui, pendapatan sebagai suatu item yang sangat penting dalam laporan keuangan khususnya laporan laba rugi perlu diukur dengan akurat.

Pengukuran adalah penentuan jumlah rupiah sebagai unit pengukur suatu objek yang terlibat dalam suatu transaksi keuangan. Jumlah rupiah hasil pengukuran akan dicatat untuk dijadikan data dasar dalam penyusunan laporan keuangan. Pengukuran lebih berhubungan dengan masalah penentuan jumlah rupiah yang dicatat pertama kali pada saat suatu transaksi terjadi, Suwardjono (2011:35).

\subsubsection{Metode Pengukuran Pendapatan}

Ada lima dasar pengukuran pendapatan (Smith, 2012:54), yaitu sebagai berikut:

1. Biaya historis (Historical Cost)

2. Biaya penggantian saat ini (Current Replacement Cost)

3. $\quad$ Nilai pasar saat ini (Current Merket Value)

4. $\quad$ Nilai bersih yang dapat direalisasi (Net Realisable Value)

5. Nilai sekarang aliran kas mendatang (Present Value Of Future Cash Flow)

2.6 Pengakuan, Pengukuran, dan Pengungkapan Pendapatan Menurut PSAK No. 23

\subsubsection{Pengakuan Pendapatan Menurut PSAK No. 23}

Ada beberapa kriteria untuk mengakui pendapatan dari penjualan jasa dalam PSAK No. 23 paragraf 19, yaitu sebagai berikut:

Jika hasil yang terkait dengan penjualan jasa dapat diestimasi secara andal, maka pendapatan sehubungan dengan transaksi tersebut diakui dengan mengacu pada tingkat penyelesaian transaksi pada akhir periode pelaporan. Hasil transaksi dapat diestimasi secara andal jika seluruh kondisi berikut ini dipenuhi:

a) jumlah pendapatan dapat diukur secara andal;

b) kemungkinan besar manfaat ekonomi sehubungan dengan transaksi tersebut akan mengalir ke entitas;

c) tingkat penyelesaian dari suatu transaksi pada akhir pelaporan dapat diukur secara andal; dan

d) biaya yang timbul untuk transaksi dan biaya menyelesaikan transaksi tersebut dapat diukur secara andal.

\subsubsection{Pengukuran Pendapatan Menurut PSAK No. 23}

PSAK No. 23 paragraf 8 menyatakan bahwa, "pendapatan diukur dengan nilai wajar imbalan yang diterima atau dapat diterima.". Nilai wajar adalah jumlah suatu aset dipertaruhkan, atau liabilitas diselesaikan antara pihak-pihak yang berkeinginan dan memiliki pengetahuan memadai dalam suatu transaksi yang wajar. Imbalan tersebut biasanya berbentuk kas atau setara kas dan jumlah pedapatan adalah jumlah kas atau setara kas yang diterima atau dapat diterima.

\subsubsection{Pengungkapan Pendapatan Menurut PSAK No. 23}

Pengungkapan pendapatan menurut PSAK No. 23 Entitas mengungkapkan:

a) kebijakan akuntansi yang digunakan untuk pengakuan pendapatan, termasuk metode yang digunakan untuk menentukan tingkat penyelesaian transaksi penjualan jasa;

b) jumlah setiap kategori signifikan dari pendapatan yang diakui selama periode tersebut, termasuk yang berasal dari:

(i) penjualan barang;

(ii) penjualan jasa;

(iii) bunga; 
(iv) royalty;

(v) dividen

c) jumlah pendapatan yang berasal dari hasil pertukaran barang atau jasa yang tercakup dalam setiap kategori signifikan dari pendapatan.

\subsection{Pedoman Kebijakan Akuntansi Peraturan Pemerintah No. 10/1990 Pada PT.} Pegadaian (PERSERO) Cabang Megamas Manado

Buku Pedoman Kebijakan Akuntansi Keuangan ini disusun sebgai rumusan dan kebijakan-kebijakan yang perlu dalam rangka penerapan prinsip-prinsip akuntansi dalam kegiatan perusahaan sehari-hari. Laporan keuangan Pegadaian disajikan secara periodik terutama laporan yang ditujukan kepada pihak-pihak eksternal yang berkepentingan, disusun dan disajikan berdasarkan ketentuan-ketentuan menurut buka pedoman ini. Buku pedoman ini dimaksudkan pula sebagai petunjuk bagi para pelaksana pada semua unit Pegadaian dalam melaksanakan kegiatan yang berhubungan dengan akuntansi keuangan khususnya dalam menyelenggarakan pencatatan dan pelaporan keuangan yang sesuai dengan prinsip-prinsip akuntansi yang lazim.

\section{METODE PENELITIAN}

\subsection{Jenis Penelitian, Jenis Data, dan Sumber Data}

\subsubsection{Jenis Penelitian}

Menurut Sugiyono (2012:86) penelitian deskriptif adalah penelitian yang dilakukan untuk mengetahui nilai mandiri, baik satu variabel atau lebih (independen) tanpa membuat perbandingan atau menghubungkan antara satu dengan variabel yang lain. Moleong (2012:4) mendefinisikan penelitian kualitatif sebagai prosedur penelitian yang menghasilkan data dekriptif berupa kata-kata tertulis atau lisan dari orang-orang dan perilaku yang dapat diamati.

\subsubsection{Jenis Data}

Arikunto (2012:22), jenis data terdiri dari data kuantitatif dan data kualitatif.

a. Data Kuantitatif

Data kuantitatif merupakan data yang menggunakan angka, mulai dari pengumpulan data, penafsiran terhadap data tersebut, serta penampilan dari hasilnya.

b. Data Kualitatif

Data kualitatif merupakan tampilan yang berupa kata-kata atau tertulis yang dicermati oleh peneliti, dan benda-benda yang diamati sampai detailnya agar dapat ditangkap maka tersirat dalam dokumen atau bendanya.

\subsubsection{Sumber Data}

Dalam penelitian ini, penulis menggunakan data kualitatif.

Sumber data yang digunakan dalam penelitian adalah data primer. Data primer adalah data dalam bentuk verbal atau kata-kata yang diucapkan secara lisan, gerak-gerak atau perilaku yang dilakukan oleh subjek yang dapat diperaya, dalam hal ini adalah subjek penelitian yang berkenan dengan variabel yang diteliti, Suharsimi Arikunto (2012:21). Dapat juga dikatakan sebagai data yang diperoleh secara langsung dari sumber asli. Data ini disebut juga data asli atau data baru yang memiliki sifat up to date.

\subsection{Tempat dan Waktu Penelitian}

Tempat Penelitian dilakukan di PT. Pegadaian Cabang Megamas Manado. Dengan melihat permasalahan yang akan diangkat pada penelitian ini, maka lamanya waktu yang digunakan untuk meneliti adalah 1 (satu) bulan.

\subsection{Prosedur Penelitian}

Prosedur penelitian adalah sebagai berikut :

1. Persiapan 

2. Observasi
3. Wawancara
4. Penelitian dan Pembahasan
5. Menarik Kesimpulan

\subsection{Metode Pengumpulan Data}

Metode pengumpulan data yang digunaka dalam penelitian ini adalah sebagai berikut:

1. Dokumentasi

2. Wawancara

3. Observasi

\subsection{Prosedur Analisis Data}

Dalam menganalisis skripsi ini, dikelompokkan dalam tiga bagian yaitu:

1. Pengakuan pendapatan dengan cara membandingkan pengakuan pendapatan yang diterapkan oleh PT. Pegadaian Cabang Megamas Manado dengan PSAK No. 23.

2. Pengukuran jumlah yang harus dicatat atas pendapatan, apakah telah sesuai dengan PSAK No. 23.

3. Pengungkapan pendapatan pada PT. Pegadaian Cabang Megamas Manado.

\section{Hasil Penelitian}

\subsubsection{Klasifikasi Pendapatan}

Dalam Pedoman Kebijakan pengertian pendapatan adalah setiap peningkatan aktiva atau penurunan atas utang perusahaan yang timbul dari aktivitas gadai dan investasi serta aktivitas usaha lainnya yang dilakukan perusahaan selama satu periode. Jenis-jenis pendapatan PT. Pegadaian adalah sebagai berikut:

1. Pendapatan Usaha

a. Pendapatan sewa modal

Pendapatan sewa modal adalah pendapatan yang diperoleh dari aktivitas yang dilakukan oleh perusahaan dalam usaha pemberian gadai. Pendapatan ini berasal dari bunga yang dibayarkan nasabah kepada PT. Pegadaian.

b. Pendapatan Administrasi

Pendapatan administrasi adalah pendapatan yang berasal dari biaya penyimpanan dan asuransi yang dibayarkan nasabah atas barang jaminan milik nasabah yang ditentukan berdasarkan golongan kredit.

2. Pendapatan Lain-lain

a. Uang Kelebihan Nasabah Yang Kadaluarsa

Pendapatan ini berasal dari penjualan barang jaminan dimana nilai penjualan lelang barang jaminan lebih besar dari pokok pinjaman, sewa modal (bunga), dan biaya lelang.

b. Pendapatan Jasa Giro

Pendapatan jasa giro merupakan bunga atas rekening giro perusahaan.

\subsubsection{Kebijakan Akuntansi Perusahaan}

PT. Pegadaian merupakan lembaga kredit yang bergerak dibidang jasa penyaluran uang pinjaman kepada masyarakat atas dasar hukum gadai dengan jaminan barang bergerak. Pada pelaksanaan kegiatan pencatatan atas semua kegiatan ekonomi PT. Pegdaian mengacu pada pedoman kebijakan akuntansi Perum Pegadaian yang sesuai dengan peraturan pemerintah Nomor 10/1990.

1. Pengakuan Pendapatan

Menurut buku pedoman kebijakan akuntansi PT. Pegadaian, pengertian pendapatan adalah setiap peningkatan aktiva atau penurunan atas utang perusahaan yang timbul dari aktivitas usaha gadai dan investasi serta aktivitas usaha lainnya yang dilakukan perusahaan selama satu periode.

2. Pengukuran Pendapatan 
Pendapatan diukur menurut harga yang terjadi dalam transaksi. Pendapatan diukur dengan nilai wajar imbalan yang diterima atau dapat diterima. Hal ini dapat dilihat dari adanya penentuan tarif sewa modal (bunga) dan tarif biaya administrasi dari tiap golongan uang pinjaman dan adanya penaksiran yang tepat terhadap barang jaminan sehingga Pegadaian bisa menentukan jumlah pendapatan yang akan diterima.

\subsubsection{Laporan Pendapatan}

Berikut ini adalah laporan pendapatan PT. Pegadaian (PERSERO) Cabang Megamas Manado Periode 2015-2016.

\subsubsection{Pengakuan dan Pengukuran Pendapatan}

Setiap pinjaman yang diberikan melalui kredit gadai pada PT. Pegadian Cabang Megamas Manado akan dikenakan sewa modal yang dalam istilah umum kita kenal dengan bunga pinjaman. Tarif sewa modal ini ditetapkan setiap 15 hari dan berdasarkan penggolongan uang pinjaman. Jika bunga dibayarkan pada hari keenambelas, besarnya bunga akan naik dua kali lipat (kelebihan 1 hari akan dihitung 15 hari). Misalnya seorang nasabah yang masuk dalam golongan A telat sehari dalam pembayaran bunganya, maka bunga yang harus dibayarkan akan dua kali lipat, yaitu sebesar 1,5\%. Begitu juga seterusnya jika terjadi keterlambatan lagi dihari berikutnya.

\section{Pengakuan Pendapatan}

Bedasarkan hasil penelitian yang dilakukan pada PT. Pegadaian Cabang Megamas Manado, sesuai dengan Pedoman Kebijakan Akuntansi berdasarkan PP No. 10/1990 Pendapatan diakui dan dicatat dalam catatan akuntansi perusahaan pada saat pengalihan hak atas pelayanan jasa yang diberikan. Berikut ini akan diuraikan bagaimana PT. Pegadaian Cabang Megamas Manado melakukan pengakuan dan pengukuran pendapatan.

\section{Pengukuran Pendapatan}

Pendapatan pada PT. Pegadaian bersumber dari kegiatan utama perusahaan dan kegiatan lainnya. Sesuai dengan Pedoman Kebijakan Akuntansi PT. Pegadaian Cabang Megamas Manado berdasarkan PP No. 10/1990 pendapatan diukur atas dasar harga yang terjadi dalam transaksi berdasarkan ketentuan (rumus) yang berlaku serta dinilai dengan satuan mata uang rupiah. Jumlah pendapatan yang diterima dari penyaluran kredit dicatat sebesar nilai perhitungan atau perkalian atas presentase sewa modal dengan pokok pinjaman dalam jangka waktu pembayaran yang telah ditentukan oleh pihak Pegadaian dan jumlah pokok pinjaman tersebut harus sesuai dengan nilai barang jaminan nasabah yang telah ditaksir.

\subsection{Pembahasan}

\subsubsection{Analisis Pengakuan Pendapatan pada PT. Pegadaian Cabang Megamas Manado}

Berdasarkan hasil penelitian pada PT. Pegadaian untuk pengakuan pendapatan ternyata mengacu pada Pedoman Kebijakan Akuntansi Keuangan sesuai dengan Peraturan Pemerintah No. 10/1990. Berdasarkan peraturan tersebut pengakuan pendapatan yang telah diterapkan oleh PT. Pegadaian Cabang Megamas Manado telah sesuai dengan PSAK No. 23 yang berlaku di Indonesia. Pengakuan pendapatan pada PT. Pegadaian Cabang Megamas Manado diakui dan dicatat dalam catatan akuntansi perusahaan pada saat pengalihan hak pelayanan jasa diberikan.

\subsubsection{Analisis Pengukuran Pendapatan pada PT. Pegadaian Cabang Megamas Manado}

Berdasarkan pengukuran pendapatan yang diperoleh Pegadaian sesuai dengan Pedoman Kebijakan Akuntansi Peraturan Pemerintah No. 10/1990, maka hal tersebut telah sesuai dengan PSAK No. 23 dimana SAK tersebut dijelaskan bahwa pendapatan diukur dengan nilai wajar imbalan yang diterima atau dapat diterima. Hal ini dapat dilihat dari adanya penentuan tarif sewa modal (bunga) dan tarif biaya administrasi dari tiap golongan uang pinjaman dan adanya penaksiran yang tepat terhadap barang jaminan, sehingga Pegadaian bisa menentukan jumlah pendapatan yang akan diterima. 


\subsubsection{Analisis Pengungkapan Pendapatan pada PT. Pegadaian Cabang Megamas Manado}

Perusahaan telah mengungkapkan kebijakan akuntansi yang digunakan untuk pengakuan pendapatan, termasuk metode yang digunakan untuk menentukan tingkat penyelesaian transaksi, hal ini dapat dilihat pada pendapatan sewa modal pada PT. Pegadaian diakui pada saat penyelesaian transaksi oleh nasabah berdasarkan SBK. Perusahaan juga mengungkapkan jumlah setiap kategori signifikan dari pendapatan yang diakui selama periode tersebut hanya termasuk pendapatan yang berasal dari penjualan jasa. Hal ini telah sesuai dengan pengungkapan pendapatan berdasarkan PSAK. No. 23.

\section{KESIMPULAN DAN SARAN}

\subsection{Kesimpulan}

Berdasarkan hasil penelitian dan analisis yang telah dilakukan, maka dapat dikemukakan kesimpulan sebagai berikut:

1. PT. Pegadaian Cabang Megamas Manado dalam melaksanakan kegiatan akuntansinya berpedoman pada Kebijakan Akuntansi Perusahaan yang pada prinsipnya tidak menyimpang dari PSAK No. 23.

2. Pendapatan perusahaan terdiri dari pendapatan usaha (operasional) dan pendapatan lain-lain (non operasional). Pendapatan usaha bersumber dari penyaluran uang pinjaman yaitu pendapatan sewa modal dan pendapatan administrasi. Pendapatan lainlain yaitu pendapatan uang kelebihan nasabah yang kadaluarsan pendapatan jasa giro dan pendapatan lainnya.

3. Pengakuan pendapatan telah sesuai dengan SAK. Pendapatan sewa modal usaha yang diperoleh oleh PT. Pegadaian Cabang Megamas Manado diakui sebagai accrual basis. Pendapatan administrasi pinjaman diakui pada saat transaksi terjadi dan dibebankan langsung kepada nasabah pada saat penyaluran pinjaman dan pada saat nasabah membayar sewa modal. Pendapatan uang kelebihan nasabah yang kadaluarsa diakui dan dicatat pada saat kadaluarsa yaitu satu tahun setelah tanggal lelang, apabila dalam jangka waktu 12 bulan uang belum diambil oleh nasabah, maka dinyatakan kadaluarsa dan diakui sebagai pendapatan oleh perusahaan. Pendapatan jasa giro diakui pada saat pihak bank mengkredit rekening giro atas nama perusahaan sebesar jumlah jasa giro yang diberikan oleh pihak bank tersebut.

4. Pengukuran pendapatan pada perusahaan dilakukan dengan menggunakan nilai wajar.

5. Perusahaan telah mengungkapkan kebijakan akuntansi yang digunakan untuk pengakuan pendapatan, untuk menentukan tingkat penyelesaian transaksi dan jumlah kategori signifikan yang diungkapkan adalah pendapatan dari penjualan jasa, telah sesuai dengan PSAK No. 23.

\subsection{Saran}

Berdasarkan kesimpulan yang telah dibuat, maka dikemukakan saran-saran sebagai berikut:

1. Pengakuan pendapatan sewa modal atas pinjaman menggunakan accrual bassis, maka peneliti menyarankan agar metode ini ditetapkan secara konsisten dan pencatatan dibuat secara konsisten juga.

2. Sehubungan dengan perubahan status perusahaan dari Perum ke PT, maka kedepan diharapkan peraturan akuntansi perusahaan dapat segera direvisi berdasarkan status perusahaan PT saat ini dan aturan yang berlaku, agar pengelolaan akuntansi dapat lebih maksimal menunjang pencapaian visi dan misi.

3. Pengakuan pendapatan uang kelebihan nasabah yang kadaluarsa yang diakui apabila dalam jangka waktu 12 bulan uang kelebihan tersebut tidak diambil oleh nasabah maka dinyatakan kadaluarsa dan diakui sebagai pendapatan oleh perusahaan, maka 
peneliti menyarankan agar pengakuan ini diberitahukan kepada nasabah atau diberikan pemberitahuan secara tertulis di Surat Bukti Kredit (SBK).

\section{DAFTAR PUSTAKA}

Arikunto, S (2012), Prosedur Penelitian: Suatu Pendekatan Praktek Rineka Cipta

Dyckman, Thomas (2012), Akuntansi Intermediate, Edisi ketiga, Jilid 1, Penerbit Erlanga Jakarta.

Harahap, Sofyan (2013), Analisis Kritis Atas Laporan Keuangan. Yogyakarta: UPPSTIM YKPN

Kieso, Weygand dan Jerry Warfield (2012). Intermediate Accounting. Edisi 12, Penerbit Erlanga, Jakarta.

Moleong, Lexy J. 2012. Metodolongi Penelitian Kualitatif, Bandung. Remaja Rosdakarya.

Peraturan Pemerintah No.10 Tahun 1990, Pedoman Kebijakan Akuntansi, Perum Pegadaian

Pontoh, Winston (2013). Akuntansi Konsep dan Aplikasi. Halaman Moeka. Jakarta

Rudianto (2013), Pengantar Akuntansi (konsep dan teknik)Penyusunan Laporan Keuangan), Penerbit Erlanga, Jakarta.

Smith, Jay M, dan K Fred Skousen (2012), Akuntansi Keuangan, Penerbit Erlangga, Jakarta

Sugiyono (2012). Metode Penelitian Kuantitatif, Kualitatif, dan R\&D. Cetakan ke-17. Bandung: Alfabeta

Suhayati Ely dan Sri Dewi Anggani (2009), Akuntansi Keuangan, Penerbit Graha Ilmu, Yogyakarta.

Suwardjono (2011), Akuntansi Pengantar, Edisi Ketiga, Penerbit Fakultas Ekonomi Universitas Gadjah Mada, Yogyakarta.

Wild, J.J, K. W. Shaw, B. Chiapetta (2014), Financial Accounting, $2^{\text {nd }}$ ed., Amerika Serikat: McGraw-Hill Education 